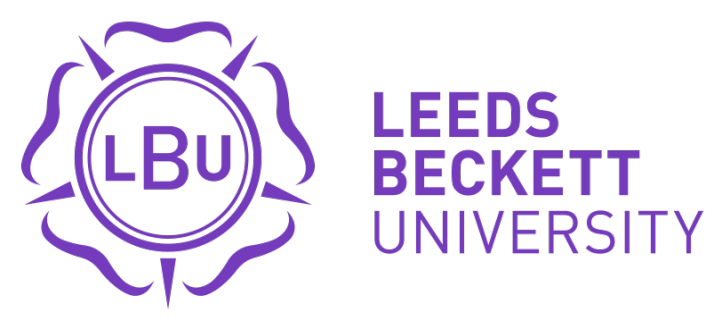

Citation:

Molinari, C (2019) Book review: Graphic assembly: montage, media and experimental architecture in the 1960s. Visual Studies. pp. 1-2. ISSN 1472-586X DOI: https://doi.org/10.1080/1472586x.2019.1672975

Link to Leeds Beckett Repository record:

https://eprints.leedsbeckett.ac.uk/id/eprint/6245/

Document Version:

Article (Accepted Version)

This is an Accepted Manuscript of an article published by Taylor \& Francis in Visual Studies on 30th September 2019, available online: http://www.tandfonline.com/10.1080/1472586x.2019.1672975.

The aim of the Leeds Beckett Repository is to provide open access to our research, as required by funder policies and permitted by publishers and copyright law.

The Leeds Beckett repository holds a wide range of publications, each of which has been checked for copyright and the relevant embargo period has been applied by the Research Services team.

We operate on a standard take-down policy. If you are the author or publisher of an output and you would like it removed from the repository, please contact us and we will investigate on a case-by-case basis.

Each thesis in the repository has been cleared where necessary by the author for third party copyright. If you would like a thesis to be removed from the repository or believe there is an issue with copyright, please contact us on openaccess@leedsbeckett.ac.uk and we will investigate on a case-by-case basis. 


\section{Graphic Assembly: Montage, Media and Experimental Architecture in the 1960s}

written by Craig Buckley

Minneapolis: University of Minnesota Press, 2019, 390 pages

ISBN: 978-1-5179-0161-5 (hardback) Price \$34.95

Reviewed by Carla Molinari, Leeds Beckett University

The book Graphic Assembly 'dwells on the enduring and unstable relationship between montage and changing problems of industrial assembly in the second half of the twentieth century' (11). Following an apparently never-ending interest in montage, Craig Buckley offers the opportunity to rethink this concept from the refreshing perspective of post-war architectural groups. Many scholars have explored montage and its relationships with architecture focusing on the 20s and 30s and on the key role of avant-garde; Buckley's original focus on the 60s aims to set 'montage within a temporal perspective structured by persistence across ruptures, part of an unfinished problematic that unfolds symptomatically around questions of assembly' (26). More specifically, the book argues that montage is an evolving array of techniques, offering a new, exciting angle in the studies of architecture and media.

Graphic Assembly is the summary of a long, deep research developed on the field - opening old, dusty boxes in forgotten archives and private collections. The book, indeed, has a very rich visual component showing key works, most of which never-before-published. Most importantly, Buckley conducts a crucial visual analysis of all this material. What is more convincing here, is the thorough description of the composition of printed pages, and the constant reference to the related physical properties of architecture. Not only the photographs are considered as industrial, mechanical products, manually cut and glued on paper, but more specifically the analysis focuses on montage procedures that 'condensed complex three-dimensional entities into composite two-dimensional surfaces' and also 'served to conceive three-dimensional structures and interiors from effects registered in two dimensions' (7). Through this visual investigation of selected works, Graphic Assembly argues the presence of a cultural common ground shared by building construction, industry and design process.

Beyond the formal and visual analysis, Buckley's research offers also historical and ideological perspectives of the use of montage, or Graphic Assembly procedures, during the 60s. There are three main critical dualities that inform the main thesis. First of all, the conflict between design - or better said disegno - over buildings at the time, and the difficulty for architects to overcome the gap between these two dimensions. Second, the relation between culture and industry, characterising the last centuries of our society and defining our tools and methods to create ideas, as well as products. Finally, the relationship between drawings and photographs, but also printed and electronic works, and the related questions about authorship of projects. Buckley does not refer to montage as method able to solve these three dilemmas, if anything he defines it as 'conceptual' and 'cultural' series of techniques that can support architects in investigate and explore further these dualities.

The book is organised in 5 main chapters, each one concentrating on a different case study about architectural groups active in London, Vienna, Paris and Florence between the late 50s 
and the early 70s. Buckley begins with an analysis on Reyner Banham's theory of 'clip-on' architecture and his 'anti-aesthetic' recodification of collage 'bound up with an interest in material and epistemological opacity, one that matched the empiricist bias of his historiography and criticism' (Chapter 1). He then revisits Archigram's plug-in concept in relation to the group attempt to synthetize printed and electronic tools (Chapter 2). He follows with an examination of Hans Hollein and Walter Pichler, and more specifically of Hollein's manifesto Everything Is Architecture and the idea of architecture as communication medium (Chapter 3). Buckley then focuses on the interdisciplinary Utopie Group and the ideological reframing of montage as method to de-assemble (Chapter 4). Finally, he describes the multimedia works of Superstudio and their use of montage as narrative tool (Chapter 5).

Graphic Assembly clearly defines montage as 'a general theoretical framework for thinking about the cultural-technical network of actors, machines, icons, behaviours, and discourses that make up the conditions of architectural visualization' (293). This quite broad thesis is convincingly supported by a carefully visual analysis of a selected body of works, and by a rich series of critical references. Surprisingly enough, there is almost no overlapping with the book Montage and the Metropolis: Architecture, Modernity, and the Representation of Space (New Haven, Connecticut: Yale University Press, 2018) written by Martino Stiërli and, as Buckley underlines, not yet available at the time of writing. Despite the differences, it is interesting to note how these books, both promising a 'comprehensive account' about montage, actually further open the debate (307). In this sense, Buckley offers stimulating, new directions, that I am sure will be taken shortly by others. 